\title{
Analysis of an Egyptian Mummy Resin by Mass Spectrometry
}

\author{
Mark L. Proefke and Kenneth L. Rinehart \\ School of Chemical Sciences, University of Illinois at Urbana-Champaign, Urbana, Illinois, USA
}

\begin{abstract}
Fast atom bombardment combined with mass spectrometry (FAB/MS), high resolution FAB/MS, FAB tandem mass spectrometry (MS/MS), and gas chromatography/mass spectrometry (GC/MS) were used to determine the composition of the resinous material recovered from the wrappings of an Egyptian mummy believed to be from the Roman period (100-350 A.D.). FAB/MS and MS/MS studies identified several oxidation products of abietic acid as the principal resin components, indicating that one or more species of coniferous trees were used by the Egyptians as a source of the resin. GC/MS studies also identified several $n$-alkanes with carbon numbers from $C_{19}$ to $C_{33}$ in the sample. The relative amounts of these $n$-alkanes, along with characteristic trace metals, indicate that bitumen, an asphalt native to the region, was added to the resin. The presence of this ancient source of carbon in this sample explains the inconsistent date assigned to the mummy by carbon-14 analysis. (I Am Soc Mass Spectrom 1992, 3, 582-589)
\end{abstract}

$A$ rchaeologists have long found themselves faced with the difficult problem of identifying unknown materials in organic remains. Of all the organic remains studied, resins are among the most common. Resins have been used throughout antiquity as coatings, as in jars and vessels, and as adhesives, as in Egyptian mummy wrappings. However, resin samples recovered from these archaeological sites are often complex mixtures, making analysis difficult. Mass spectrometry has played a vital role in the analysis of these samples. Wright and Wheals [1] used pyrolysis-mass spectrometry to classify several natural gums, resins, and waxes found in Egyptian cartonnages. Resin samples from transport amphoras recovered from a late Bronze Age shipwreck were analyzed using gas chromatography/mass spectrometry (GC/MS) by Mills and White [2]. The presence of several triterpenoids (identified as their methyl esters) indicated that the resin was from a Pistacia species, probably $P$. attantica. Hairfield and Hairfield [3] confirmed this result by using thin layer chromatography (TLC). Beck et al. [4-6] have studied resin remains from several shipwrecks by using mass spectrometry, infrared spectroscopy, and TLC. Their studies found several characteristic diterpenoids, identifying the resins as pine pitches. Perhaps the most thorough analysis of an Egyptian mummy resin sample was the work of Benson et al. [7]. Their study of the resin from Mummy 1770, unwrapped at the Manchester

Address reprint requests to Kenneth L. Rinehart, School of Chemical Sciences, University of Illinois at Urbana-Champaign, $1209 \mathrm{~W}$. California Street, Urbana, IL 61801.
Museum, utilized GC, TLC, atomic absorption spectroscopy, and several chemical spot tests in addition to mass spectrometry.

In many of these studies the principal resin components identified were highly polar diterpenoic or triterpenoic acids. In each case these polar carboxylic acids had to be converted to nonpolar methyl esters prior to analysis by $\mathrm{CC}$ or mass spectrometry. $\Lambda$ primary goal of the present research was to use fastatom bombardment combined with mass spectrometry ( $\mathrm{FAB} / \mathrm{MS}$ ) or with tandem mass spectrometry (FAB/MS/MS) to identify the resin acids in an Egyptian mummy resin without prior chromatographic separation or derivatization.

\section{Mummy History}

The focus of this study was an Egyptian mummy recently acquired by the World Heritage Museum on the University of Illinois campus [8]. The museum purchased the mummy from a private collector and very little was known about it other than its origin in the Fayum district of Egypt. An interdisciplinary research program was initiated by the University of Illinois Program on Ancient Technologies and Archaeological Materials to determine the age, sex, and medical history of the mummy and to gain insight into the embalming procedures employed.

The mummy was subjected to several nondestructive studies including radiography, computer axial tomography scans, and magnetic resonance imaging $[8,9]$. A small sample of the wrappings was obtained 
from the mummy where the feet were broken off. The fibers in this sample were subjected to textile analysis and the embalming resin recovered from the wrappings was used as the sample in the present study. Approximately $100 \mathrm{mg}$ of material was provided by the museum.

In addition, a carbon-14 date was obtained for the mummy from the cedar stiffening board used in the embalming procedure [8]. The date obtained, $2140 \pm$ 160 radiocarbon years $\mathrm{BP}$, corresponds to approximately 190 B.C. This was slightly older than expected based on the decorations on the mummy wrappings. The gold leaf and face portrait suggested that the mummy was from the Roman period of ancient Egypt (100-350 A.D.). A common practice of Roman period embalmers was to add bitumen, an asphalt native to the region, to the embalming resin. The presence of such an ancient source of carbon would definitely affect the carbon-14 date. As a result, the museum also requested that the analysis check for bitumen in the sample.

\section{Experimental}

Sample preparation. The terpenoic acids in the mummy resin were first obtained by base extraction. A small portion of the resin sample was dissolved in $\mathrm{CHCl}_{3}$ and twice extracted with a saturated $\mathrm{NaHCO}_{3}$ solution. The aqueous layers were combined and acidified with $\mathrm{HCl}$. The aqueous layer was then back extracted twice with $\mathrm{CHCl}_{3}$ and concentrated to give a $10 \mu \mathrm{g} / \mu \mathrm{L}$ solution. Esters were prepared for comparison to known compounds using methanolic $\mathrm{HCl}$. The original $\mathrm{CHCl}_{3}$ solution containing the basic and neutral components was filtered and concentrated to a $10-\mu \mathrm{g} / \mu \mathrm{L}$ solution for subsequent analysis.

Mass spectrometry. FAB mass spectra were obtained on a VG ZAB-SE mass spectrometer (VG Instruments, Manchester, UK) operating at $8 \mathrm{kV}$ with a resolution of 1000. A 3:1 mixture of dithiothreitol/dithioerythritol, or "magic bullet" [10], was used as the FAB matrix. Ten micrograms of the resin sample in 1 $\mu \mathrm{L}$ of $\mathrm{CHCl}_{3}$ were placed on the probe along with approximately $5 \mu \mathrm{L}$ of matrix. Xenon was used as the bombarding gas at a potential of $8 \mathrm{kV}$ and $1.2 \mathrm{~mA}$ current.

High resolution FAB (HRFAB) measurements and $F A B / M S / M S$ product ion scans were obtained on a VG 70-SE4F mass spectrometer of EBEB geometry. Similar operating conditions were employed with the exception of instrument resolution, which was set to 10,000 for the HRFAB measurements and 1000 for the product ion scans. HRFAB measurements were obtained by peak matching using matrix peaks, and tandem mass spectra were produced by collisional activation using helium in a collision cell located between the first magnetic and second electric sectors. The parent ion signal intensity was attenuated $90 \%$ by the collision gas and the cell was held at $4 \mathrm{kV}$.
Gas chromatography/mass spectrometry. GC/MS data were collected on an HP 5970 (Hewlett-Packard, Palo Alto, CA) GC/MSD equipped with an HP 5890 GC. Splitless injections were made onto a $30-\mathrm{m} \mathrm{SE}-30$ capillary column with an internal diameter of $0.25 \mathrm{~mm}$ (Alltech Assoc., Deerfield, IL). The injector and detector were held at $250^{\circ} \mathrm{C}$ and $275{ }^{\circ} \mathrm{C}$, respectively. The oven was linearly ramped from $100^{\circ} \mathrm{C}$ to $250^{\circ} \mathrm{C}$ at $20^{\circ} \mathrm{C} / \mathrm{min}$ and then held at $250^{\circ} \mathrm{C}$. Helium was used as the carrier gas with a head pressure of 5 psi.

Atomic emission spectroscopy. Trace elements were measured by atomic emission at the University of Illinois Microanalytical Laboratory by using a Perkin Elmer Plasma II Emission Spectrometer. Quantitative measurements of $\mathrm{Na}, \mathrm{Mg}, \mathrm{Al}, \mathrm{P}, \mathrm{K}, \mathrm{Ca}, \mathrm{Ti}, \mathrm{V}, \mathrm{Mn}, \mathrm{Fe}$, $\mathrm{Ni}, \mathrm{Cu}, \mathrm{Zn}, \mathrm{Sr}, \mathrm{Zr}, \mathrm{Mo}$, and $\mathrm{Sn}$ were obtained. The resin sample was digested in a quartz crucible over an open flame using a mixture of nitric and sulfuric acids and hydrogen peroxide until a clear solution was obtained. Appropriate blanks were also run.

\section{Results and Discussion}

Resin acids. Both true resins and gum resins were employed by the Egyptians in embalming fluids [11b]. True resins were the most common and can be divided into those produced by conifers and those from non-cone-bearing trees. Conifers native to the eastern Mediterranean region included the Lebanon cedar (Cedrus libuni), Cilician fir (Abies cilicica), Aleppo pine (Pinus halepensis), stone pine (Pinus pinea), and the Oriental spruce (Picea orientalis) [11b]. These trees produce oleoresins containing at least one of five primary diterpenoid acids, all of which isomerize to abietic acid, 1, upon aging [12].

The nonconiferous true resins available, terebinth and mastic, were obtained from several different Pistacia species. These materials contain several characteristic triterpenoic acids [2].

The gum resins frankincense and myrrh were used less frequently by the Egyptians in embalming fluids. Frankincense, or olibanum, is obtained from Boswellia spp. [13] and contains several triterpenoids that differ from those found in terebinth and mastic [14]. Myrrh is collected from several Commiphora species and contains several characteristic furanosesquiterpenes in the resin fraction [15].

Our Egyptian mummy resin was expected to contain hundreds of components, most at trace levels. To simplify the analysis, the resin sample was first fractionated into acidic and neutral components by base extraction. It should be noted at this point that the resin sample was very heterogeneous, consisting of a number of small pieces impregnated with bits of linen, sand, and other inorganic materials. The brown coloring was inconsistent from piece to piece. On average, $75 \%$ of the resin sample was soluble in chloroform and the acidic components recovered from the base 
extraction represented approximately $30 \%$ of the total sample weight. Because the principal components of the acidic fraction were expected to be any of the terpenoic acids listed above, FAB was chosen as the mass spectrometric ionization technique due to its ability to produce strong $[\mathrm{M}+\mathrm{H}]^{+}$ions with these polar, nonvolatile compounds.

The low resolution FAB mass spectrum of the acidic fraction is shown in Figure 1, with the peaks from the matrix marked with asterisks. No significant peaks were observed in this spectrum above $m / z 400$ indicative of the triterpenoid containing resins terebinth, mastic, and frankincense. High resolution measurements of the most intense high mass ions are presented in Table 1 . The 20 carbons in the molecular formulas of $[\mathrm{M}+\mathrm{H}]^{+}$ions with nominal masses 331 , 315 , and 299 suggest that these compounds are a series of diterpenoids, each differing from the next by a single oxygen atom. The three peaks at masses 285 , 269 , and 253 also differ by a single oxygen atom and correspond to loss of $\mathrm{COOH}$ and $\mathrm{H}$ from the three $\mathrm{C}_{20}[\mathrm{M}+\mathrm{H}]^{+}$peaks. This loss is characteristic of a carboxylic acid functional group, further identifying the unknowns as diterpenoic acids. The sample also contains some sodium, evident from the $[\mathrm{M}+\mathrm{Na}]^{+}$ ions at $m / z 337$ and 353, corresponding to the $[\mathrm{M}+$ $\mathrm{H}]^{+}$peaks at $m / z 315$ and 331, respectively.

Chromatographic separation of carboxylic acids is ofter difficult due to compound retention by the stationary phase. To avoid this step MS/MS was used to characterize individual compounds separately in the mixture, withoul prior chromatography. The FAB/MS/MS product ion scan of the most abundant $[\mathrm{M}+\mathrm{H}]^{+}$ion observed in the low resolution FAB spectrum, $m / z$ 315, is shown in Figure 2 . This diterpenoic acid had the molecular formula $\mathrm{C}_{20} \mathrm{H}_{27} \mathrm{O}_{3}$ and contained one additional oxygen atom and two fewer hydrogen atoms than dehydroabietic acid, 2 ([M + $\mathrm{H}^{+}=\mathrm{C}_{20} \mathrm{H}_{29} \mathrm{O}_{2}$ ), suggesting that the mummy compound was an oxo derivative of this very common resin acid. A comparison of the product ions observed
Table 1. High resolution FAB mass spectrometric data for acids

\begin{tabular}{lccc}
\hline $\begin{array}{l}\text { Nominal } \\
\text { mass }\end{array}$ & $\begin{array}{c}\text { Exact } \\
\text { mass }\end{array}$ & $\begin{array}{c}\text { Molecular } \\
\text { formula }\end{array}$ & $\begin{array}{c}\text { Error } \\
(\mathrm{mmu})\end{array}$ \\
\hline \hline 331 & 331.1906 & $\mathrm{C}_{20} \mathrm{H}_{27} \mathrm{O}_{4}$ & +0.3 \\
315 & 315.1965 & $\mathrm{C}_{20} \mathrm{H}_{27} \mathrm{O}_{3}$ & -0.5 \\
299 & 299.2008 & $\mathrm{C}_{20} \mathrm{H}_{27} \mathrm{O}_{2}$ & -0.3 \\
285 & 285.1856 & $\mathrm{C}_{19} \mathrm{H}_{25} \mathrm{O}_{2}$ & -0.1 \\
269 & 269.1902 & $\mathrm{C}_{19} \mathrm{H}_{25} \mathrm{O}$ & +0.3 \\
253 & 253.1956 & $\mathrm{C}_{19} \mathrm{H}_{25}$ & -0.4 \\
187 & 187.1123 & $\mathrm{C}_{13} \mathrm{H}_{15} \mathrm{O}$ & -0.0 \\
\hline
\end{tabular}

in this $\mathrm{FAB} / \mathrm{MS} / \mathrm{MS}$ spectrum to the electron ionization fragment ions published for methyl dehydroabietate [16] revealed a remarkable similarity (Scheme I). Both compounds showed the loss of a methyl and an acid/ester functional group ( $a$ and $h$ ions, as described in ref 16). Both spectra also showed a strong $m / z 43$ ion due to the isopropyl group.

The FAB/MS/MS product ion scan of the unknown diterpenoic acid also contained $b$ and $c$ ions $\mathbf{1 4}$ $\mathrm{u}$ higher than those found in the methyl dehydroabietate spectrum. High resolution measurements of $m / z$ 187 observed in the low resolution spectrum ${ }^{1}$ yielded the ionic formula $\mathrm{C}_{13} \mathrm{H}_{15} \mathrm{O}$, supporting the proposed structure of the $c$ ion [16] and locating the oxo derivative between carbons 6 and 14 on the abietane skeleton. Oxidation at C-7 is favorable due to the allylic nature of this carbon; and, in fact, 7-oxo-dehydroabietic acid, 3, has previously been found in an archaeological resin sample by Beck et al. [4]. An authentic sample of this compound was obtained for comparison to the unknown. The methyl ester of the unknown was readily obtained by esterification of the unknown acid by addition of methanolic $\mathrm{HCl}$ to an

\footnotetext{
The FAB mass spectrum of a methyl 7-oxodehydroabietate standard showed an $m / z 187$ fragment ion with an abundance similar to that observed in the low resolution $\mathrm{FAB}$ mass spectrum of the resin acids.
}

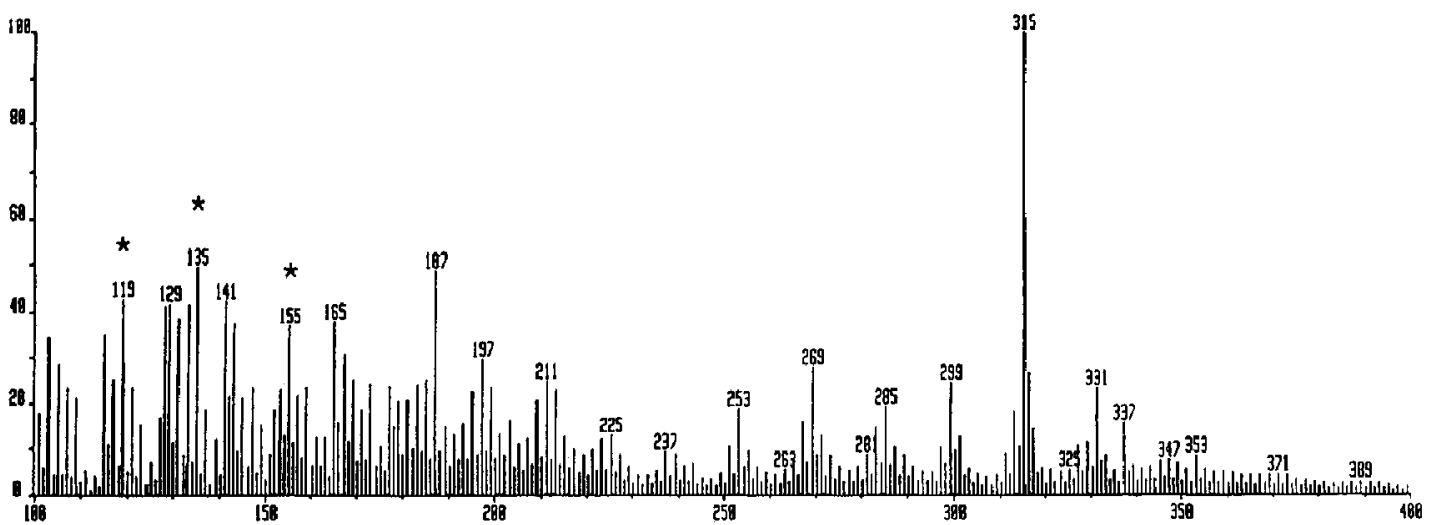

Figure 1. Low resolution $F A B$ mass spectrum of the mummy resin acid fraction. * $=$ matrix peaks. 


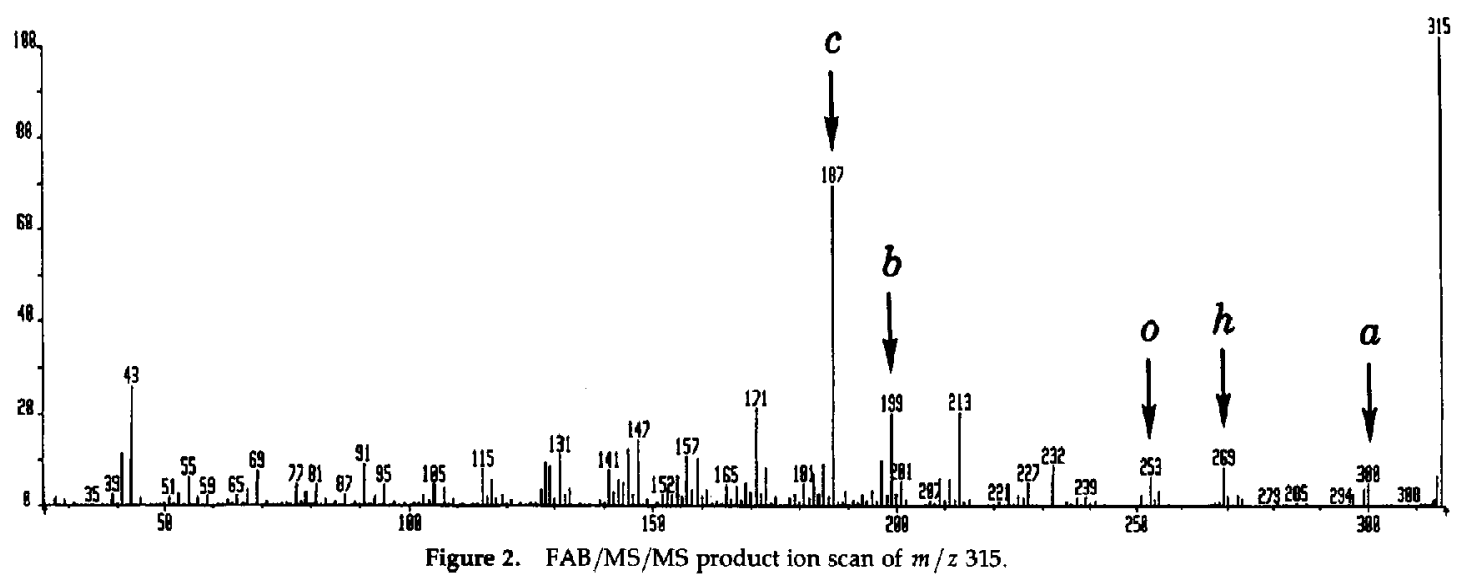

aliquot of the crude resin mixture. The FAB/MS/MS scans of the unknown and standard methyl esters shown in Figure 3 were identical, confirming the assigned structure.

The molecular formula $\mathrm{C}_{20} \mathrm{H}_{27} \mathrm{O}_{4}$ of the $\mathrm{m} / \mathrm{z} 331$ peak contained one more oxygen than the $\mathrm{m} / \mathrm{z} 315$ peak and was expected to be an oxidation product of 7-oxodehydroabietic acid. The tandem mass spectrum of this compound is shown in Figure 4. The location of the additional oxygen atom can be determined from the spectral and chemical information. The presence of an $\left[\mathrm{M}-\mathrm{H}_{2} \mathrm{O}\right]^{+}$ion at $m / z 313$ suggests that the additional oxygen exists as an hydroxyl and not a

\begin{tabular}{cccc} 
Ion & $\begin{array}{c}\text { Methyl } \\
\text { Dehydroabietate* } \\
\mathrm{R}=\mathrm{CH}_{3}, \mathrm{X}=\mathrm{H}, \mathrm{H}\end{array}$ & $\begin{array}{c}\text { Unknown } \\
\text { Resin Acid } \\
\mathrm{R}=\mathrm{H}, \mathrm{X}=\mathrm{O}\end{array}$ & Loss \\
\hline$a$ & 299 & 300 & $-\mathrm{CH}_{3}$ \\
$h$ & 255 & 269 & $-\mathrm{COOR}$ \\
$o$ & 239 & 253 & - COOR, $-\mathrm{H}_{2}-\mathrm{CH}_{3}$ \\
$b$ & 185 & 199 & see below \\
$c$ & 173 & 187 & see below
\end{tabular}

*From Reference 16.

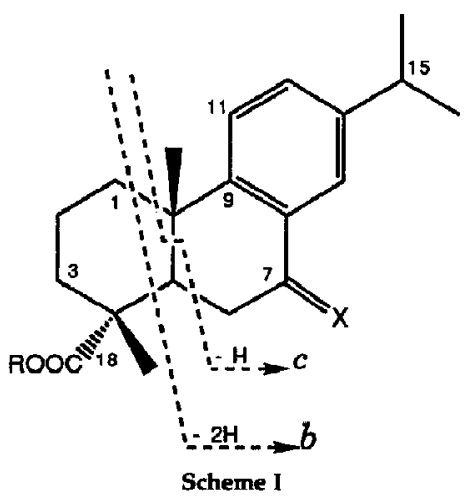

phenolic group. Chemically, the easiest carbons to oxidize would be those benzylic to the aromatic ring (C-7, already oxidized, and C-15 in the isopropyl group). This compound, 15-hydroxy-7-oxodehydroabietic acid, 4, is shown in Scheme II. Locating the hydroxyl group here is supported by the mass spectral data. All of the product ions outlined in Scheme I for the $\mathrm{m} / z 315$ ion were found to be $16 \mathrm{u}$ higher for

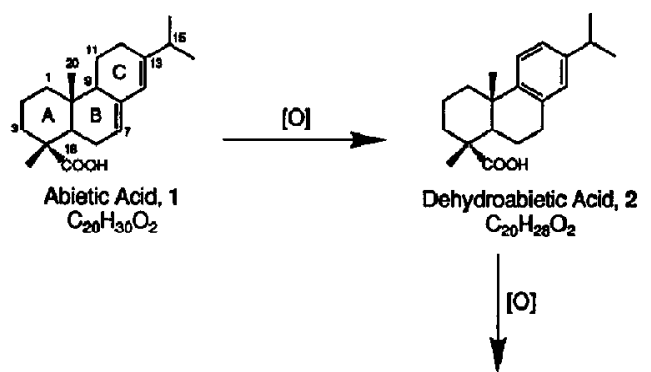

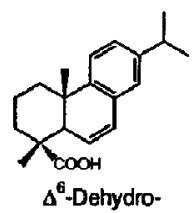
abietic Acid 5 $\mathrm{C}_{20} \mathrm{H}_{26} \mathrm{O}_{2}$

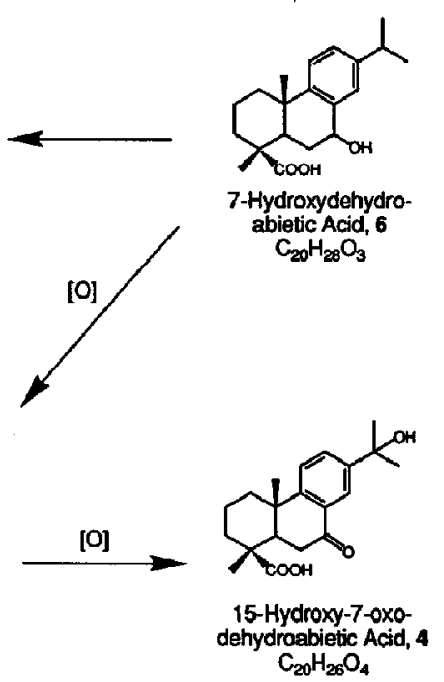

Scheme II ietic Acid, 3 $\mathrm{C}_{20} \mathrm{H}_{26} \mathrm{O}_{3}$ 

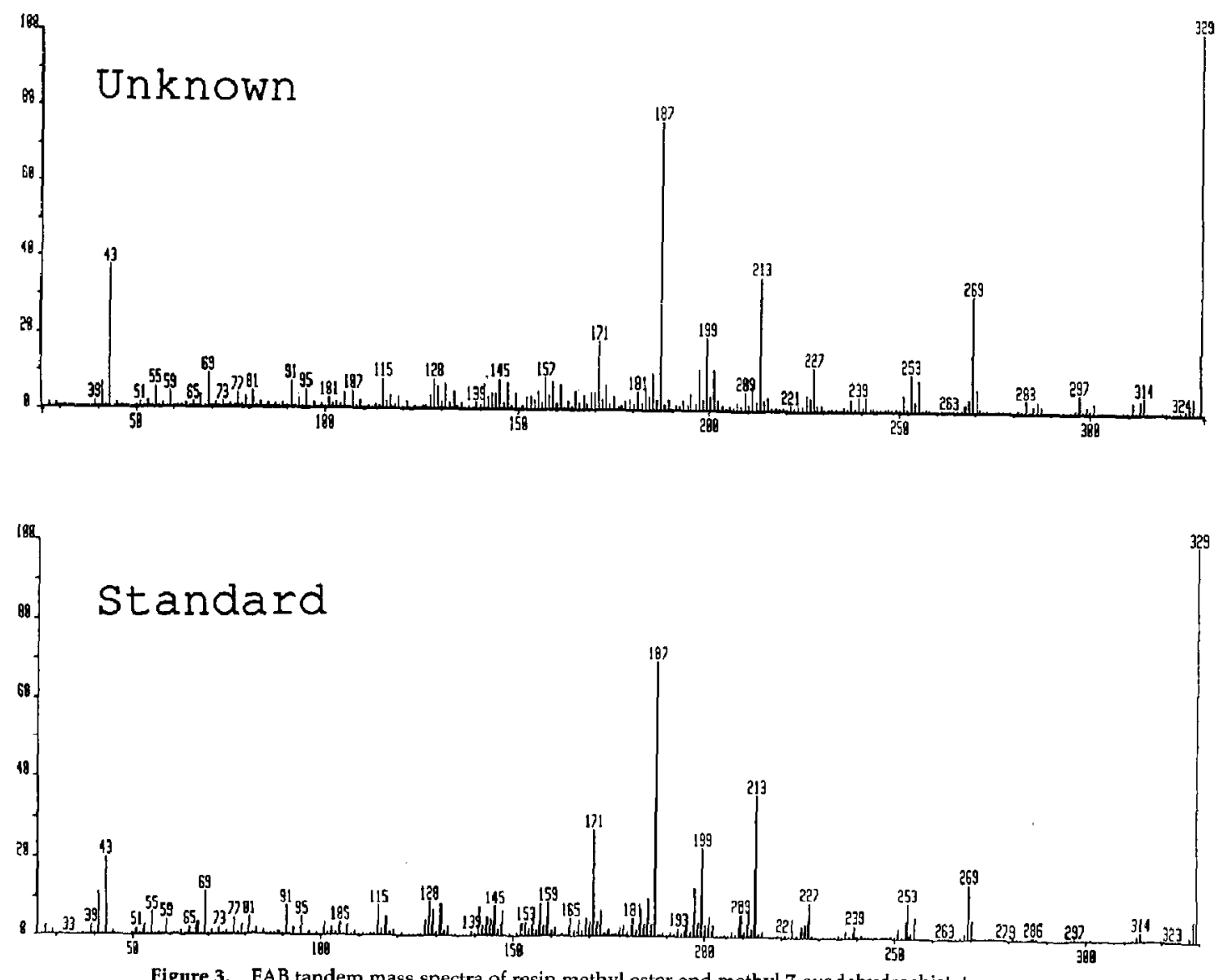

Figure 3. FAB tandem mass spectra of resin methyl ester and methyl 7-oxodehydroabietate.

the $m / z 331$ ion (see Figure 4). In each case the postulated structure for the product ion includes the isopropyl group. Additionally, a new fragment observed at $m / z 59$ can be assigned to the $\left(\mathrm{CH}_{3}\right)_{2} \mathrm{COH}^{+}$ fragment.
The third peak, $m / z 299$, is more than likely frum a precursor in the oxidation pathway to the two compounds already identified in this sample. The molecular formula $\mathrm{C}_{20} \mathrm{H}_{27} \mathrm{O}_{2}$ of the $m / z 299$ ion indicates that this compound lacks the oxo group and contains

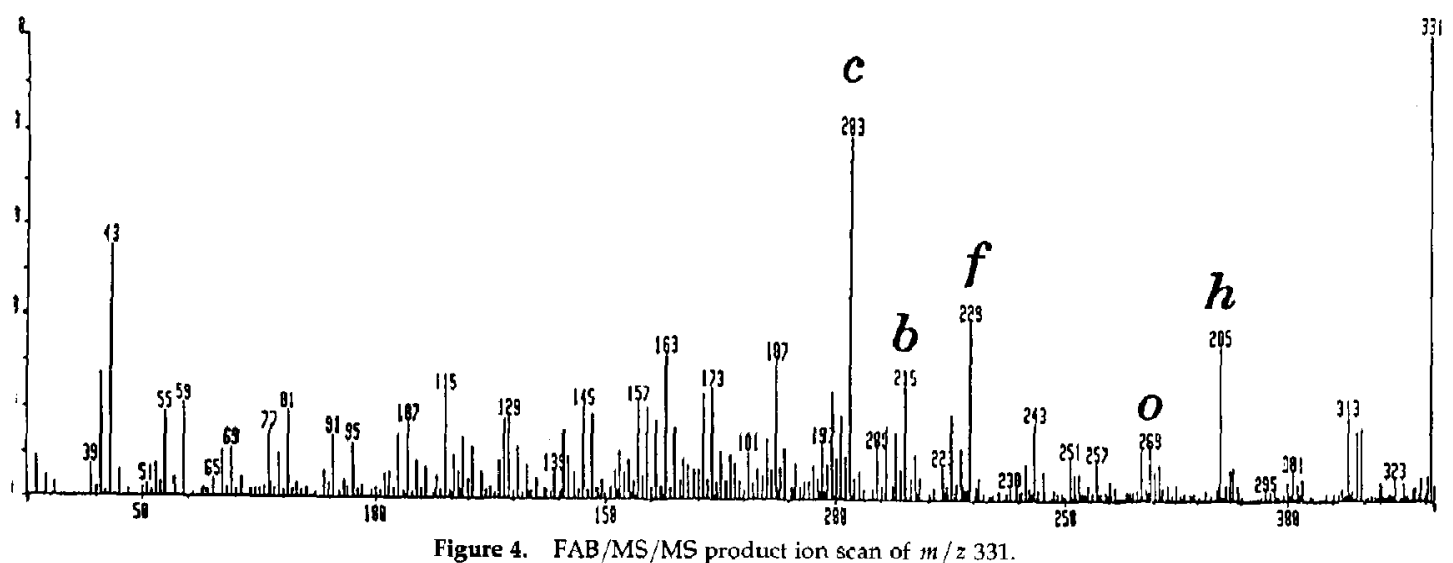

Figure 4. FAB/MS/MS product ion scan of $m / z 331$. 


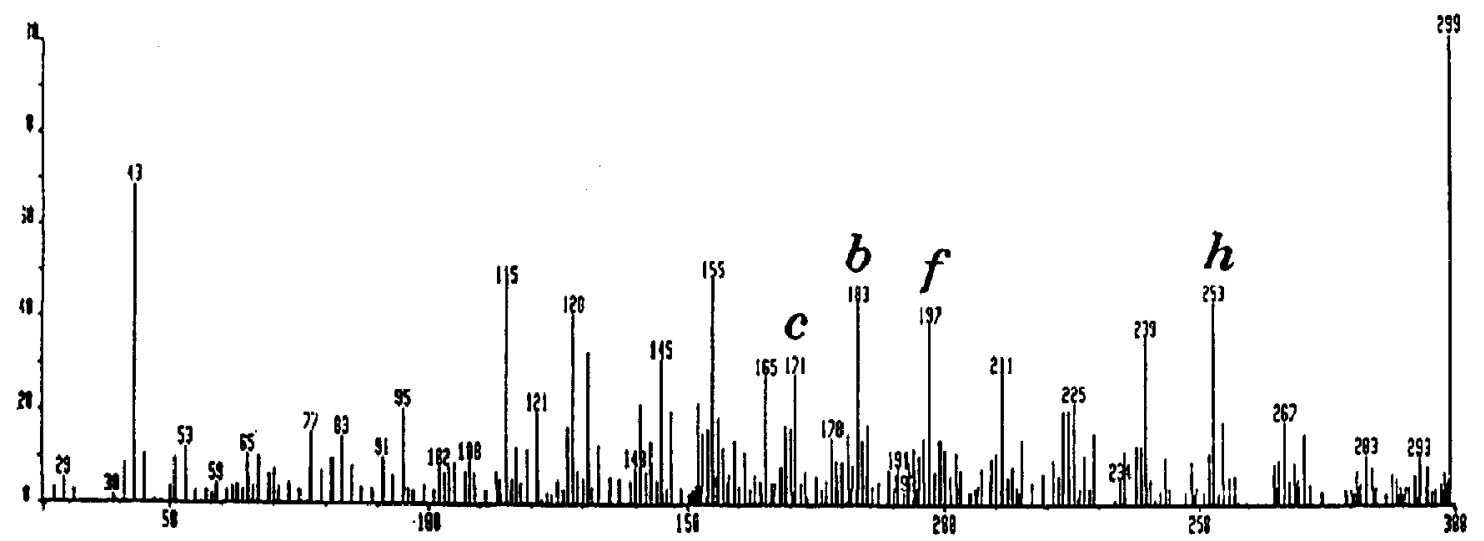

Figure 5. FAB/MS/MS product ion scan of $m / z 299$.

one more double bond than 7-oxodehydroabietic acid. The location of this additional double bond can be determined from the FAB/MS/MS product ion scan shown in Figure 5 . Because the tandem mass spectrum contains $b, c, f$, and $h$ fragment ions $16 u$ less than those observed for 7-oxodehydroabietic acid, one can assume that the aromatic " $\mathrm{C}$ " ring is intact. As previously discussed, $\mathrm{C}-7$ and $\mathrm{C}-15$ are the most easily oxidized due to their positions adjacent to the aromatic ring, locating the double bond between either carbons 6 and 7 or carbons 15 and 16. The presence of a strong $m / z 43$ peak in Figure 5 indicates that the isopropyl group is intact, locating the double bond between carbons 6 and 7 . This compound, $\Delta^{6}$ dehydroabietic acid, 5, can arise from dehydration of 7-hydroxy-dehydroabietic acid, 6, which is also a reasonable precursor to 7-oxodehydroabietic acid, 3.

Bitumen. The presence of a petroleum product in the mummy resin was expected, based on the inconsistent carbon-14 date obtained for the sample. The addition of even a small portion of such an ancient carbon source would make the material appear much older than it actually is. There were no native petroleum sources found in Egypt; however, bitumen was actively traded throughout the region at the time of the preparation of this mummy [11a]. Bitumen is produced when petroleum seeps to the surface of the earth and is washed downstream to the sea. Initially, it contains numerous saturated and aromatic hydrocarbons, heterocompounds, and asphaltenes [17]. As the material ages, the more volatile components are lost and it undergoes substantial chemical oxidation to produce a semisolid mass. The use of bitumen by the Egyptians in mummification is not universally accepted [11a]; however, evidence of its use in several Persian and Roman period mummies has been documented [18-20].

Table 2 shows the GC/MS data obtained for the neutral fraction of our mummy resin, where several $n$-alkanes with chain lengths of 19 to 33 carbons were found. The $C_{19}$ to $C_{26}, C_{28}$, and $C_{30}$ compounds were positively identified based on comparison of the retention time and the mass spectrum of each GC peak to those of a standard. The other $n$-alkanes were assigned by extrapolation of retention times and characteristic mass spectra (Figure 6). The distribution of the $n$-alkanes is shown graphically in Figure 7 [21].

There were two possible sources of long chain saturated hydrocarbons available to the ancient Egyptians: bitumen and waxes of insect or plant origin. The typical dominance of odd over even n-alkanes found in beeswax and terrestrial plants [22] was not observed in this sample. In addition, myricyl palmitate $\left(\mathrm{C}_{15} \mathrm{H}_{31} \mathrm{COOC}_{30} \mathrm{H}_{61}\right)$, which makes up $70 \%$ of beeswax [7], was not detected. The more equal even to odd distribution of saturated hydrocarbons found here matches that in bitumen [17] and is very similar to that found by other researchers in archaeological resin samples. Beck and Borromeo [6] found a series of $n$-alkanes with chain lengths from 22 to 32 carbons

Table 2. GC/MS of the neutral fraction

\begin{tabular}{ccc}
\hline $\begin{array}{c}\text { Peak retention time } \\
\text { (min) }\end{array}$ & $\begin{array}{c}\text { Peak height } \\
(\mathrm{cm})\end{array}$ & n-Alkane \\
\hline \hline 9.7 & 6.0 & $\mathrm{C}_{19} \mathrm{H}_{40}$ \\
10.6 & 10.0 & $\mathrm{C}_{20} \mathrm{H}_{42}$ \\
11.6 & 16.0 & $\mathrm{C}_{21} \mathrm{H}_{44}$ \\
12.9 & 23.0 & $\mathrm{C}_{22} \mathrm{H}_{46}$ \\
14.5 & 24.5 & $\mathrm{C}_{23} \mathrm{H}_{48}$ \\
16.5 & 22.0 & $\mathrm{C}_{24} \mathrm{H}_{50}$ \\
19.0 & 16.0 & $\mathrm{C}_{25} \mathrm{H}_{52}$ \\
22.3 & 9.0 & $\mathrm{C}_{26} \mathrm{H}_{54}$ \\
26.6 & 5.5 & $\mathrm{C}_{27} \mathrm{H}_{56}$ \\
32.0 & 3.0 & $\mathrm{C}_{28} \mathrm{H}_{58}$ \\
39.0 & 2.0 & $\mathrm{C}_{29} \mathrm{H}_{60}$ \\
48.3 & 1.0 & $\mathrm{C}_{30} \mathrm{H}_{62}$ \\
60.1 & 0.9 & $\mathrm{C}_{31} \mathrm{H}_{64}$ \\
75.6 & 0.3 & $\mathrm{C}_{32} \mathrm{H}_{66}$ \\
95.6 & 0.1 & $\mathrm{C}_{33} \mathrm{H}_{68}$ \\
\hline
\end{tabular}




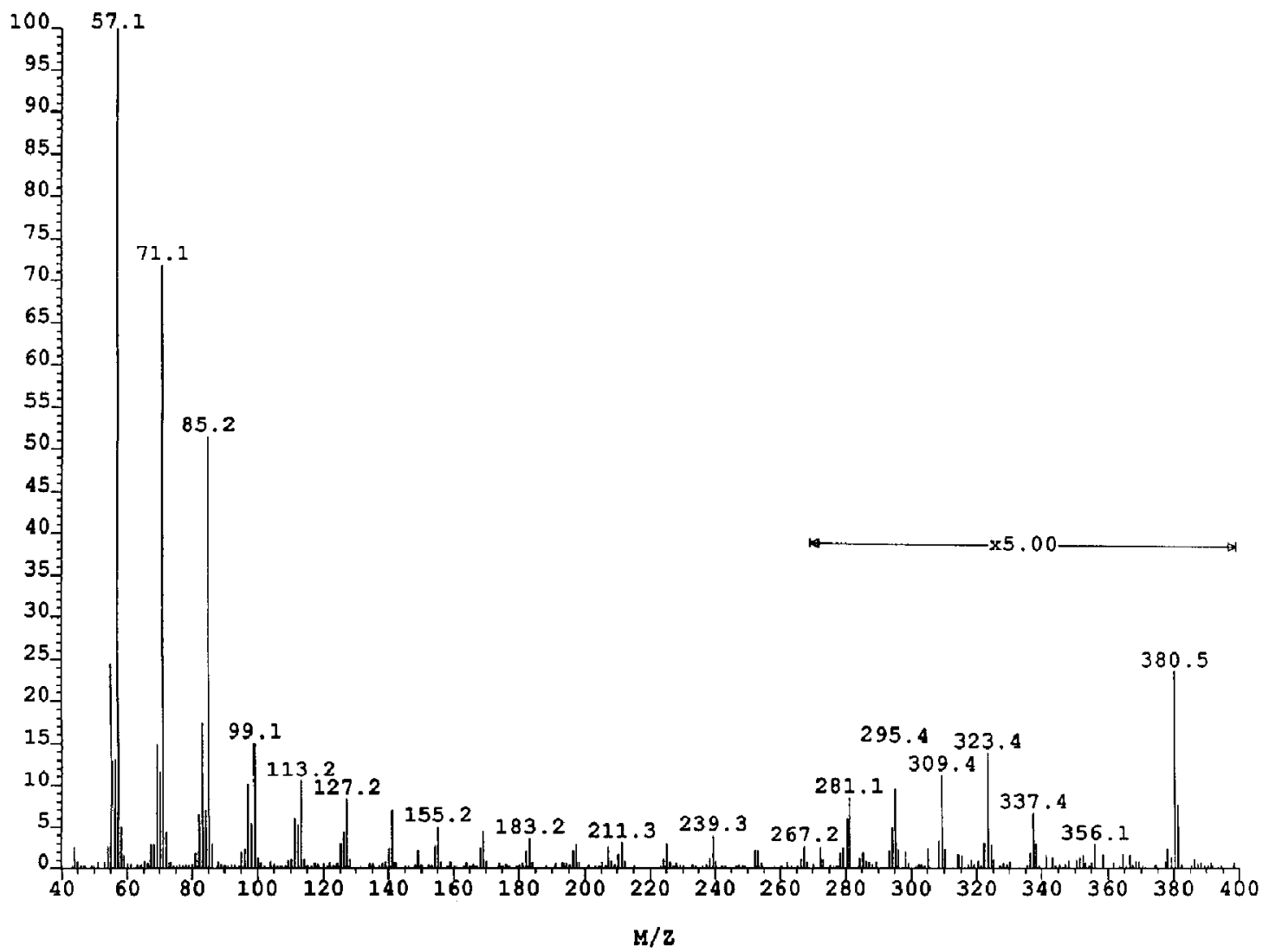

Figure 6. GC mass spectrum of $n$-alkane with retention time 26.6 minutes $\left(\mathrm{C}_{27} \mathrm{H}_{56}\right)$.

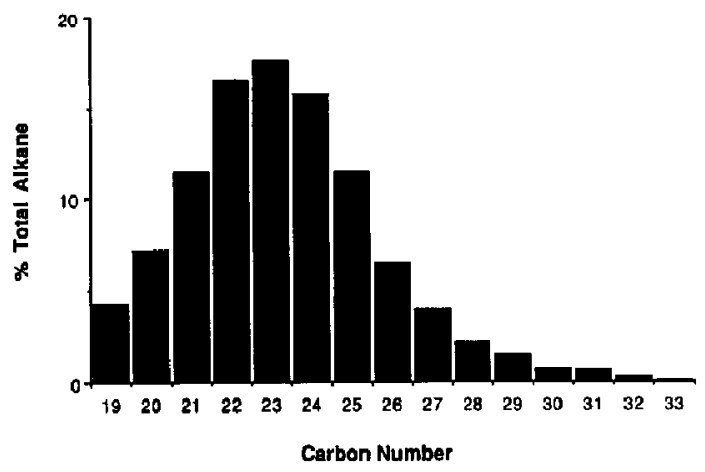

Figure 7. Distribution of $n$-alkanes in the mummy resin. Reprinted with permission from Rinehart, K. L.; Proefke, M. L. Anal. Chem. 1992, 64, 108. Copyright @ 1992 American Chemical Society.

in the neutral fraction of a resin sample and concluded from their distribution that petroleum was added to the pine pitch. Benson et al. [7] found a similar distribution of alkanes $\left(\mathrm{C}_{21}-\mathrm{C}_{33}\right)$ in the Mummy 1770 resin and suggested that a hydrocarbon of some sort was added to the embalming fluid.

Further evidence for bitumen in the mummy resin
Table 3. Trace element analysis of mummy resins and bitumens $^{\mathrm{a}}$

\begin{tabular}{cccccc}
\hline Element & $\begin{array}{c}\text { Illinois } \\
\text { mummy } \\
\text { resin }\end{array}$ & $\begin{array}{c}\text { Dead Sea } \\
\text { bitumen }^{b}\end{array}$ & $\begin{array}{c}\text { Meso- } \\
\text { potamian } \\
\text { bitumen }^{c}\end{array}$ & $\begin{array}{c}\text { PUM II } \\
\text { resin }^{d}\end{array}$ & $\begin{array}{c}1770 \\
\text { resin }^{\circ}\end{array}$ \\
\hline \hline $\mathrm{Ni}$ & 33.4 & 251 & $10-200$ & 7.3 & ND $^{\mathrm{e}}$ \\
$\mathrm{V}$ & 65.9 & 463 & $30-300$ & $\mathrm{ND}$ & 11.0 \\
$\mathrm{Mo}$ & 17.4 & 219 & NA $^{\mathrm{f}}$ & 4.0 & 93.8 \\
\hline
\end{tabular}

${ }^{\text {In }}$ parts per million.

LFrom ref. 7 .

${ }^{\mathrm{C}}$ Fram ref. 23

${ }^{d}$ From ref. 24.

Not detected.

${ }^{\mathrm{f}}$ Not available.

can be found in the trace metal analysis. Bitumen contains several trace metals that are not leached out with aging. The metals most characteristic of bitumen are nickel and vanadium; however, molybdenum has also been indicated [19]. Marschner and Wright [23] found $\mathrm{Ni}$ levels ranging from 10 to $200 \mathrm{ppm}$ and $\mathrm{V}$ levels of 30 to $300 \mathrm{ppm}$ in several natural bitumens from Mesopotamian sites, while Benson et al. [7] found $251 \mathrm{ppm} \mathrm{Ni}$ and 463 ppm V, along with 219 ppm Mo, in authentic Dead Sea bitumen. Table 3 shows the result of the atomic emission study of our 
resin sample where $33.4 \mathrm{ppm} \mathrm{Ni}, 65.9 \mathrm{ppm} \mathrm{V}$, and $17.4 \mathrm{ppm}$ Mo were found, confirming the addition of bitumen to the resin. Several additional elements were quantified in the mummy resin and are summarized in Table 4.

\section{Conclusions}

The three oxidation products of abietic acid found in the mummy resin clearly indicate that a true conifer resin was used as the base for the embalming fluid. Identification of the exact species of tree used was not possible because abietic acid is a common isomerization product of nearly all naturally produced coniferous diterpenes. Also, the material had undergone substantial chemical oxidation. Undoubtedly, the sample contains several more components; however, the structures of these additional components were not pursued due to their low concentrations and the paucity of original resin material. Positive identification of a resin base could be made with the three compounds already determined.

In addition, the use of bitumen by the Egyptians in the preparation of this mummy was confirmed by the presence of several $n$-alkanes and trace metals in the resin sample. This was not entirely unexpected for a mummy prepared in the Roman period and supports the use of bitumen in later period Egyptian mummies. The use of bitumen also explains the inconsistent carbon-14 date obtained for this artifact.

\section{Acknowledgments}

The authors thank the University of Illinois Program on Ancient Technologies and Archaeological Materials for providing the sample of the mummy resin and the invitation to participate in this project. We also thank Dr. Curt W. Beck, Vassar College, Poughkeepsie, New York, for samples of methyl dehydroabietate and methyl 7-oxodehydroabietate; Dr. Richard Milberg and Furong Sun of the University of Illinois School of Chemical Sciences Mass Spectrometry Laboratory for assistance with the

Table 4. Additional elements found in the Illinois mummy resin

\begin{tabular}{cccc}
\hline Element & $\begin{array}{c}\text { Parts per } \\
\text { million }\end{array}$ & Element & $\begin{array}{c}\text { Parts per } \\
\text { million }\end{array}$ \\
\hline $\mathrm{Na}$ & 10600. & $\mathrm{Mn}$ & 36.2 \\
$\mathrm{Mg}$ & 1540. & $\mathrm{Fe}$ & 571. \\
$\mathrm{Al}$ & 557. & $\mathrm{Cu}$ & 7.7 \\
$\mathrm{P}$ & $\mathrm{ND}^{\mathrm{a}}$ & $\mathrm{Zn}$ & $\mathrm{ND}^{\mathrm{a}}$ \\
$\mathrm{K}$ & 301. & $\mathrm{Sr}$ & 78.5 \\
$\mathrm{Ca}$ & 9190. & $\mathrm{Zr}$ & $\mathrm{ND}$ \\
$\mathrm{Ti}$ & 59.7 & $\mathrm{Sn}$ & $\mathrm{ND}$ \\
\hline
\end{tabular}

\footnotetext{
${ }^{\text {a }}$ Not detected.
}

mass spectrometry; and Thomas McCarthy and Judith Proefke of the University of Ilinois School of Chemical Sciences Microanalytical Laboratory for the trace element analysis.

This work was funded in part by a grant from the National Institute of General Medicine Sciences (GM27029, to KLR) and in part by a University Scholar Award (to KLR). MLP would like to thank Phillips Petroleum and the Department of Education for fellowship support.

\section{References}

1. Wright, M. M.; Wheals, B. B. J. Anal. Appl. Pyrolysis 1987, 11, 195-211.

2. Mills, J. S.; White, R. Archaeometry 1989, 31, 37-44.

3. Hairfield, H. H. Jr.; Hairfield, E. M. Anal. Chem. 1990, 62, $41 A-45 A$.

4. Beck, C. W.; Smart, C. J.; Ossenkop, D. J. In Archael. Chem. 4; Allen, R. O., Ed.; Adv. Chem. Ser., Vol. 220; American Chemistry Society: Washington, 1989; pp 369-380.

5. Beck, C. W.; Ossenkop, D. J. In The Kyrenia Wreck; Katzev, M. L., Ed.; in preparation.

6. Beck, C. W.; Borromeo, C. Submitted for publication in MASCA Res. Pap. Sci. Archaeol. 1990, 7, 51-58.

7. Benson, G. G.; Hemingway, S. R.; Leach, F. N. In Manchester Mummy Project; David, A. R., Ed.; Manchester University: Manchester, 1979; pp 119-131.

8. Wisseman, S.; Klepinger, L.; Keen, R.; Raheel, M.; Barkmeier, J. In Proceedings of the International Symposium on Archaeometry; Birkhauser Verlag AG: Basel, 1990.

9. Wisseman, S. U.; Proefke, M. L.; Lawrence, D. P. Submitted for publication in Archaeomaterials.

10. Witten, J. L.; Schaffer, M, H,; O'Shea, M,; Cook, J. C.; Hemling, M. E.; Rinehart, K. L. Jr. Biochem. Biophys. Res. Commun. 1984, 124, 350-358.

11. (a) Lucas, A.; Harris, J. R. Ancient Egyptian Materials and Industries, 4th ed.; Histories \& Mysteries of Man: London, 1989; pp 303-308. (b) Ibid, 376-324.

12. Simonsen, J.; Barton, D. H. R. The Terpenes, Vol III; Cambridge University: Cambridge, 1952; $\mathrm{p} 380$.

13. The Merck Index, 9th ed.; Windholz, M., Ed.; Merck: Rahway, NJ, 1976; p 888.

14. Xaasan, C. F.; Minale, L.; Bashir, M.; Hussein, M.; Finamore, E. Rend. Accad. Sci. Fis. Mat., Naples 1984, 51, 93-96.

15. Maradufu, A.; Warthen, J. D. Jr. Plant Sci. 1987, 57, 181-184.

16. Enzcll, C. R.; Wahlberg, I. Acta. Chem. Scand. 1969, 23, 871-891.

17. Spiro, B.; Welte, D. H.; Rullkotter, J.; Schaefer, R. G. Bull. Am. Assoc. Pet. Geol. 1983, 67, 1163-1175.

18. Zaki, A.; Iskander, Z. Ann. Serv. 1943, 62, 223.

19. Spielmann, P. E. J. Egypt. Archaeol. 1932, 18, 177-180.

20. Rullkotter, J.; Nissenbaum, A. Naturuissenschaften 1988, 75 , 618-621.

21. Proefke, M. L.; Rinehart, K. L.; Raheel, M.; Ambrose, S. H.; Wisseman, S. U. Anal. Chem. 1992, 64, 105A-111A.

22 Douglas, A. G.; Eglinton, G. In Comparative Phytochemistry; Swain, T., Ed; Academic: London, 1966; Chapter 4.

23. Marschner, R. F.; Wright, H. T. In Archaeol. Chem. 2; Carter, G. F., Ed.; Adv. Chem. Ser., Vol. 171; American Chemistry Society: Washington, 1978; pp 150-171.

24. Cockburn, A.; Cockburn, E. Mummies, Disease, and Ancient Cultures; Cambridge University: Cambridge, 1980; pp 61-62. 